\title{
Derechos y obligaciones de contratistas y Administración en la fase de ejecución del contrato administrativo
}

\author{
Santiago González-Varas Ibáñez \\ Profesor Titular de Derecho Administrativo
}

\begin{abstract}
SUmario: 1. GARANTÍAS DEL CONTRATISTA Y PRERROGATIVAS DE LA ADMINISTRACIÓN. 2. INALTERABILIDAD Y MUTABILIDAD DEL CONTRATO ADMINISTRATIVO. 3. EL PRINCIPIO DE RIESGO Y VENTURA. A) Riesgo y ventura y fuerza mayor. B) Frente a la apariencia inicial del supuesto debe aplicarse el principio de riesgo y ventura. $C$ ) El revés de la cuestión: no debe aplicarse el principio de riesgo y ventura del contratista. 4. EL IUS VARIANDI. A) La regulación. B) La primera garantía del contratista: la anulatoria frente a la orden que decreta el ius variandi. C) La segunda garantía del contratista: la indemnizatoria y sus límites. D) La tercera garantía: la resolución del contrato. 5. EL PRINCIPIO DE ENRIQUECIMIENTO INJUSTO. 6. EL RIESGO IMPREVISIBLE. 7. EL FACTUM PRINCIPIS. 8. LA REVISIÓN DE PRECIOS. A) Definición y presupuestos de la revisión de precios. B) Delimitación de la revisión de precios con otros supuestos, en especial el riesgo y ventura del contratista. 9. DERECHOS Y OBLIGACIONES DE LAS PARTES CONTRATANTES EN EL MOMENTO DEL PAGO DEL PRECIO Y DEL INCUMPLIMIENTO CONTRACTUAL. A) El pago de la prestación realmente realizada. B) Responsabilidades en caso de demora. B.1) Demora del contratista en le ejecución de las obras. B.2) Demora de la Administración en el pago de las certificaciones. B.3) Demora de la Administración en la iniciación, recepción, liquidación del contrato o pago por estos conceptos. C) La idea de reparación integral y el beneficio industrial. 10. GARANTÍAS Y FIANZAS. 11. LOS MECANISMOS DE COMPENSACIÓN DEL CONTRATISTA EN LOS CONTRATOS DE CONCESIÓN DE OBRAS PÚBLICAS CON EL EJEMPLO DE LAS AUTOPISTAS.
\end{abstract}

\section{GARANTÍAS DEL CONTRATISTA Y PRERROGATIVAS DE LA ADMINISTRACIÓN}

Cuando se trata el tema de los «derechos y obligaciones de contratistas y Administración en la fase de ejecución del contrato» suele hablarse directamente de las "garantías del contratista» frente a las «prerrogativas de la Administración», ya que dicho tema se ha enfocado tradicionalmente desde este punto de vista garantista.

En principio, sería conveniente realizar alguna aclaración o precisión sobre dicho tema, diciendo que «las garantías» también se refieren a las garantías de recurso y de arbitraje (véase el art. 60 de la LCAP), así como 
a aquéllas de los licitadores en fase de adjudicación del contrato (STS de 19 de enero de 1995, Ar. 546; de 21 de febrero de 1983, Ar. 897; de 9 de mayo de 1995, Ar. 3599; STJ de Canarias, de 19 de noviembre de 1998, RJCA 1998\4643) ${ }^{1}$.

Siguiendo el enfoque habitual al que supra me refería, sobre las garantías y prerrogativas en fase de ejecución del contrato, habría que empezar citando el fundamental artículo 59 de la LCAP donde se prevén las prerrogativas administrativas de interpretar los contratos administrativos, resolver las dudas que ofrezca su complimiento, modificarlos por razones de interés público, acordar su resolución y determinar los efectos de ésta.

Jurisprudencialmente se admite además la realización por parte de la Administración de auditorías contra las empresas contratistas siempre que aquéllas respeten principios básicos de proporcionalidad, adecuación al fin $(. . .)^{2}$.

En el plano de las garantías este mismo precepto (art. 59 de la LCAP) establece la garantía de audiencia en favor del contratista y la obligación de la Administración de solicitar informe en determinados casos (véanse los apartados 2 y 3 del citado art. 59 de la LCAP).

Por lo que se refiere en particular a la prerrogativa administrativa de interpretar los contratos administrativos, es doctrina asentada que «la facultad de interpretar los contratos mediante un acto administrativo, justificada por la prevalencia del interés público al que aquéllos se vinculan y porque se aconseja no demorar su ejecución como consecuencia de eventuales dudas que se susciten en relación con las obligaciones que se generen, es siempre una interpretación transitoria y provisional. No hay en el ejercicio de dicha prerrogativa discrecionalidad alguna, sino sujeción a las reglas de hermenéutica jurídica, y la última palabra corresponde al control judicial» (STS de 15 de febrero de 1999, Ar. 915; igualmente STS de 20 de abril de 1999, Ar. 4636).

Podría discutirse si, más que de garantías del contratista, sería más correcto hablar de «derechos y obligaciones de contratistas y Administración en la fase de ejecución del contrato", situando entonces, como obje-

\footnotetext{
1 Por otra parte, dejemos también claro que, para la LCAP, el tema de las «garantías» no alude sino a las «garantías» provisionales y definitivas, especiales o complementarias reguladas, entre otros preceptos en los artículos 35 a 47. Sobre este tema, por todos, F. Castillo Blanco, REDA 106, 2000 , pp. 165 y ss.
}

2 STS de 15 de octubre de 1999, Ar. 9573. 
to principal de estudio, la «relación jurídica» entre el contratista y la Administración y por tanto sus derechos y obligaciones recíprocos conforme a su definición por la legislación ${ }^{3}$. A veces será necesario garantizar al contratista frente a la Administración (aplicando por ejemplo el principio del enriquecimiento injusto de la Administración) y otras veces será necesario hacer ver al contratista que el litigio planteado debe resolverse aplicando el principio de «riesgo y ventura del contratista». El problema jurídico fundamental en torno al presente tema viene a ser un problema de calificación jurídica, es decir, de determinar en el caso concreto qué principio (ius variandi, factum principis, enriquecimiento injusto, riesgo y ventura, riesgo imprevisible, revisión de precios, etc.) debe aplicarse realmente a los efectos de resolver los litigios entre contratista y Administración.

Es común que, frente a la apariencia inicial, sea preciso descubrir la verdad subyacente; en este sentido, no es infrecuente que las partes contratantes califiquen el litigio conforme a uno $\mathrm{u}$ otro de los principios que acaban de ser mencionados debiendo el órgano jurisdiccional descubrir y mostrar la verdad existente decidiendo cuál de aquéllos puede ser legítimamente invocado en el caso concreto.

Como dice una STS de 6 de julio de 1998, Ar. 5740, si bien «es verdad que este Tribunal ha venido reconociendo de modo reiterado los principios en que se sustenta la reclamación que en este recurso se formula», «en cada recurso laten unas circunstancias fácticas que pueden obligar a soluciones distintas, en función de las especiales circunstancias que en el caso cuestionado se plantean» (lo que lleva a calificar el asunto de forma distinta a como lo había hecho el contratista recurrente).

\section{INALTERABILIDAD Y MUTABILIDAD DEL CONTRATO ADMINISTRATIVO}

Como reconoce una STS de 21 de enero de 1992, Ar. 628 (ponente E. Escusol Barra), «la realidad es que los contratos administrativos son, ordinariamente, acuerdos de larga duración y no exentos de complejidades a la hora de ejecutar lo convenido, por las circunstancias imprevisibles (de orden técnico o económico) que puedan aparecer: de ahí que el principio fundamental contractus lex inter partes venga afectado, en la contra-

\footnotetext{
${ }^{3}$ Sobre este enfoque de la "relación jurídica» puede verse S. GonzÁlez-VARAS IbáNez, Comentarios a la Ley de la jurisdicción contencioso-administrativa, Editorial Tecnos, Madrid, 2000, con otras referencias bibliográficas.
} 
tación administrativa, por otro principio: el de mutabilidad del contrato administrativo que aparece explicitado en los artículos (...)».

Asimismo, «dentro del ámbito del principio de mutabilidad del contrato, la doctrina refleja la existencia de un áleas administrativo (modificación del contrato por acción unilateral de la Administración); de un áleas empresarial (riesgos del negocio en los que late en buena medida la conducta equivocada del constructor); y de un áleas económico (debido a circunstancias externas de dificil previsión que, de producirse, pueden hacer mucho más oneroso para el contratista el cumplimiento del contrato). Este último caso, es decir, el hecho de producirse circunstancias objetivas externas de no fácil previsión y no imputables a las partes contratantes justifica las cláusulas de revisión de precios que tiende al restablecimiento del equilibrio financiero del contrato alterado por acontecimientos imprevistos».

En definitiva, es el propio interés público el que prevalece sobre la inalterabilidad del contrato (STS de 8 de noviembre de 1994, Ar. 8503), aunque dicha alterabilidad produce como consecuencia la aplicación de los debidos mecanismos de compensación en favor del contratista.

\section{EL PRINCIPIO DE RIESGO Y VENTURA}

\section{A) Riesgo y ventura y fuerza mayor}

Siguiendo la STS de 30 de abril de 1999, Ar. $4691^{4}$, el «principio de que las obras han de realizarse a riesgo y ventura del contratista, de modo que éste no tendrá derecho a indemnización por causa de pérdidas, averías o perjuicios ocasionados en dichas obras, sino en los casos de fuerza mayor, ha sido interpretado en el sentido de que el contratista asume el riesgo de poder obtener ganancia mayor o menor [e incluso perder cuando sus cálculos están mal hechos o no responden a las circunstancias sobrevenidas en la ejeución del contrato de obras (...)]».

El principio de riego y ventura encuentra límite en la causa de fuerza mayor (art. 144 de la LCAP respecto del contrato de obras).

En la jurisprudencia se ha considerado fuerza mayor el supuesto de los daños ocasionados por lluvias torrenciales que producen movimientos de terreno en la zona donde están construidas las obras (STS de 20 de mayo

${ }^{4}$ Esta STS se basa a su vez en otra de 20 de enero de 1984, Ar. 170. 
de 1999, Ar. 5201) o aquel de las inundaciones catastróficas producidas por desbordamiento de ríos (STSS de 2 de junio de 1999, Ar. 5750 y de 6 de junio de 1997, Ar. 5219), así como la «sedición populan» producida como consecuencia de la decisión de la Administración de construir una segunda presa en Riaño (STS de 11 de mayo de 1999, Ar. 5034).

\section{B) Frente a la apariencia inicial del supuesto debe aplicarse el principio de riesgo y ventura}

En efecto, podrá ocurrir que el contratista intente hacer ver que el supuesto encaja dentro del «riego imprevisible» o de la «revisión de precios» o del «enriquecimiento sin causa», o cualquier otra forma de reajuste del equilibrio económico del contrato, cuando en realidad dicho supuesto ha de resolverse aplicando el principio de riesgo y ventura del contratista.

El problema jurídico en este contexto consiste esencialmente en dilucidar si se ha producido o no una alteración de las condiciones pactadas inicialmente que lleve consigo una sobrevenida y mayor onerosidad debido por ejemplo al aumento de los precios de la materia prima o al advenimiento de circunstancias excepcionales.

Ilustrativa es en este contexto una STS de 6 de julio de 1998, Ar. 5740. Primeramente descarta, frente a la alegación de la parte recurrente, la aplicación de los principios de factum principis, el ius variandi y el riesgo imprevisible: «la doctrina que sostiene el derecho indemnizatorio en función del factum principis, ius variandi y riesgo imprevisible, presupone supuestos en los que el cumplimiento del contrato, considerado como un todo, deviene en gravemente dificultoso para una de las partes. En el contrato aquí contemplado no se produce esta dificultad grave, del cumplimiento del contrato, considerado como un todo; el mayor coste para el contratista se deriva del aumento de precios (en la materia prima utiliza$\mathrm{da}^{5}$ ), de un elemento que tiene escasa importancia cuantitativa en el contrato examinado y parece obvio que la modificación de cualquier elemento del contrato no puede dar lugar a la revisión contractual».

Seguidamente, esta STS confirma la sentencia recurrida en tanto en cuanto negó ésta la aplicación de la figura de la revisión de precios, ya que el contrato contenía una fórmula de revisión de precios donde no se incluía el concepto reclamado y porque dicha fórmula de revisión permi-

\footnotetext{
${ }^{5}$ La frase entre paréntesis es nuestra.
} 
tía al contratista obtener una compensación frente a los perjuicios, de modo que, de acceder a la pretensión de la parte se produciría una duplicidad de indemnizaciones. Por tanto, el contratista ha de asumir los posibles desequilibrios económicos producidos.

En esta misma línea, el supuesto podrá incardinarse dentro del riesgo y ventura del contratista frente a la alegación de su parte de presentarse circunstancias extraordinarias y anormales que hayan alterado las condiciones de ejecución del contrato. El párrafo que se selecciona seguidamente es un ejemplo de aplicación interesante del riesgo y ventura en este contexto:

«En el caso que nos ocupa no se han producido unas circunstancias extraordinarias y anormales que hayan alterado las condiciones de ejecución de la obra establecidas en el propio contrato o que constituyen las bases fundamentales sobre las que se contrató. Se ha producido un hecho (el cierre de la servidumbre) que ha afectado los cálculos que el contratista hizo para formular su oferta (el estudio que sirvió de base a la licitación, en palabras de la empresa recurrente), cálculos que partían de la idea de que podría trabajarse por las dos bocas o accesos al túnel de San Adrián. Se ha producido una mayor dificultad en la ejecución de los trabajos, pero debemos subrayarlo, en relación con los cálculos que la propia empresa había hecho para tomar parte en el concurso-subasta. En consecuencia debe aplicarse el principio de riesgo y ventura» (STS de 30 de abril de 1999, Ar. 4691).

Se ha estimado también que el supuesto debe resolverse a la luz del riesgo y ventura del contratista cuando éste realiza unilateralmente, es decir, por su cuenta y sin contar con autorización de la Administración, excesos de obras respecto de los convenidos, sin que dichas obras produzcan un enriquecimiento en favor de la Administración (STS de 7 de octubre de 1999, Ar. 9035).

De especial interés práctico serían en este contexto los casos de «aumentos de salario de personal» que trabaja para el contratista. Es por ejemplo incardinable dentro del riesgo y ventura del contratista el caso enjuiciado por la STS de 15 de noviembre de 1994, Ar. 8514. El Tribunal va descartando la aplicación de los distintos mecanismos de compensación en favor del contratista para concluir que el incremento de los gastos de personal que tuvo que soportar la empresa como consecuencia del plus de nocturnidad es una circunstancia que debió preverse en la oferta hecha por el contratista a la Administración, además de una facultad de organización del servicio que corresponde al empresario. 
Tampoco la elevación salarial producida como consecuencia de un convenio colectivo de empresa podrá ser causa suficiente para determinar la revisión de precios del contrato de prestación del servicio de recogida de basuras. Así lo decreta la STS de 8 de noviembre de 1994, Ar. 8503, concluyendo que la revisión de precios no ha de llevarse a cabo sino en la forma prevista en el contrato: «los incrementos de los gastos de personal originarán la revisión de precios siguiendo las leyes presupuestarias». No se admitió, pues, que los incrementos salariales fueran un acontecimiento ajeno a la voluntad del concesionario (véase también el art. 152.3 del RSCL ${ }^{6}$ ).

En suma, en este caso, las cantidades no satisfechas por la revisión de precios, como consecuencia del incremento de salarios, después de aplicar la fórmula de revisión pactada en el contrato y cifrada en las leyes presupuestarias, debían asumirse por el propio contratista (constituyen por tanto su riesgo y ventura).

Por contrapartida, es claro que este supuesto de los incrementos salariales podrá dar lugar a la revisión de precios (sin considerarse dentro del riesgo y ventura). En este sentido, la STS de 6 de octubre de 1992, Ar. 7763 sienta que «si bien ese plus (salarial) trae causa de un acuerdo de la empresa con sus trabajadores la causa inmediata del exigible durante el período de prórroga del contrato es atribuible a una disposición oficial de naturaleza imperativa», además de estar así convenido por las partes contratantes en el presente supuesto.

Tampoco procede aplicar el principio de riesgo y ventura en los ejemplos que siguen.

\section{C) El revés de la cuestión: no debe aplicarse el principio de riesgo y ventura del contratista}

Junto al límite referido supra (la fuerza mayor) tanto la legislación (LCAP) como la jurisprudencia afirman ciertos principios que consiguen evitar un posible excesivo rigor del riesgo y ventura del contratista. A los órganos jurisdiccionales del orden contencioso-administrativo corresponderá decidir en caso de conflicto si el supuesto en cuestión merece ser resuelto conforme a los principios de compensación económica en favor del contratista (por ejemplo, riesgo imprevisible, enriquecimiento injusto) o conforme al de riesgo y ventura.

\footnotetext{
${ }^{6}$ Pueden consultarse, igualmente, la STS de 2 de diciembre de 1988, Ar. 9451 y la STS de 18 de enero de 1997, Ar. 175 (Sentencia apelada, FJ 6. ${ }^{\circ}$ ).
} 
En este sentido, el principio de riesgo y ventura del contratista «no sólo quiebra en los sucesos de fuerza mayor, sino también cuando la Administración contraviene el tenor del contrato, produciendo una alteración en su ejecución» (STS de 15 de junio de 1999, Ar. 6449).

Y aunque no se trate, a diferencia de la sentencia que acaba de citarse, de una "contravención», la Administración podrá hacer uso legítimo de su potestad de modificar el contrato ocasionando una alteración del régimen contractual inicialmente pactado. El interés de calificar el asunto de esta manera está en que, aunque dicho ius variandi es una prerrogativa de la Administración, el contratista tendrá en estos casos derecho a obtener la debida compensación. Entonces, aquello que aparentemente se presentó como un supuesto de riesgo y ventura del contratista era en realidad un caso de modificación unilateral del proyecto por la Administración, con el consiguiente derecho de aquél a ser compensado por los excesos (STS de 24 de diciembre de 1997, Ar. 9622, FJ 3. ${ }^{\circ}$ ).

En general, en muchos de los supuestos que seguidamente van a comentarse el órgano jurisdiccional, frente a la apariencia inicial del litigio, debe negar en el caso concreto la aplicación del principio de riesgo y ventura del contratista.

\section{EL IUS VARIANDI}

\section{A) La regulación}

Según suele decirse, en principio estamos (con el ius variandi) ante una prerrogativa de la Administración, la de introducir modificaciones por razones de interés público una vez perfeccionado el contrato (art. 101 de la LCAP).

Sin embargo, no siempre la Administración ejercita una prerrogativa propia ya que puede ocurrir que el ejercicio del ius variandi se produzca como consecuencia de una decisión de la Comisión Europea que inste al Estado miembro a modificar el contrato (STS de 2 de febrero de 2000, Ar. 319) ${ }^{8}$.

\footnotetext{
${ }^{7}$ Así pues, es preciso estar atentos para revelar la verdad subyacente al supuesto planteado y evitar un posible interesado encaje, por parte de la Administración, del supuesto dentro del riesgo imprevisible (en este sentido véase también la STS de 24 de septiembre de 1999, Ar. 10014 FJ 5. ${ }^{\circ}$ ).

${ }^{8}$ Véase con distintos ejemplos S. González-Varas IBáÑez, El Derecho administrativo europeo, LAAP, Sevilla, 2000.
} 
Para poder modificar unilateralmente el contrato la LCAP exige «interés público» (art. 59) y presupone que hayan surgido necesidades nuevas o causas imprevistas que justifiquen las modificaciones decretadas (art. 101).

Cuando éstas sean iguales a un 10 por 100 o más del precio primitivo del contrato (y siempre que éste sea igual o superior a mil millones de ptas.) se exigen además los informes que menciona el artículo 101.3 de la LCAP.

En la regulación de la LCAP sobre el contrato de obras se especifica que serán obligatorias para el contratista las modificaciones en el contrato de obras que produzcan aumento, reducción o supresión de las unidades de obra (art. 146.1 de la LCAP).

En la regulación de la LCAP sobre el contrato de gestión de servicios públicos, frente a esta potestad de ius variandi (art. 163.1 de la LCAP), se reconoce el derecho (del contratista) a ser compensado por la Administración por las modificaciones que afecten al régimen financiero del contrato de manera que se mantenga el equilibrio económico (art. 163.1 de la LCAP) ${ }^{9}$.

\section{B) La primera garantía del contratista: la anulatoria frente a la orden que decreta el ius variandi}

Junto a la jurisprudencia (STS de 18 de octubre de 1979, Ar. 3371) la doctrina viene insistiendo tanto en la posibilidad y legitimidad del ius variandi como en la necesidad de compensar al contratista mediante una indemnización que le compense de los perjuicios que aquélla le ocasione ${ }^{10}$.

Ahora bien, las garantías del contratista, frente al ius variandi, no pueden limitarse a la indemnización de daños y perjuicios, ya que la propia potestad de modificar unilateralmente el contrato ha de tener, $y$ de hecho tiene, algunos límites lógicos.

Interesante sobre el particular es una STS que llega a negar a la Administración el ejercicio del ius variandi. Me refiero a la STS de 10 de febrero de 1997, Ar. 1137, en la que se entra a enjuiciar si «el Ayuntamien-

\footnotetext{
9 Para los dictámenes del Consejo de Estado sobre el ius variandi puede verse C. Horgué BaENA, La modificación del contrato administrativo de obra, Madrid, 1997, pp. 131 y ss.

${ }^{10}$ Por todos, puede verse cualquiera de las ediciones de E. Garcta DE ENTERRIA/T. R. Fernández, Curso de Derecho administrativo, tomo I, Madrid.
} 
to podía o no modificar las condiciones de la concesión en el particular que aquí se examina, o sea, exigiéndole a la actora la instalación de sus oficinas en su término municipal».

A pesar de que la LCAP prevé esta potestad administrativa, «esta facultad discrecional tiene un fundamento que al mismo tiempo es su límite, y que asimismo señala el indicado precepto: el interés público. En otro caso, el ejercicio del ius variandi que se reconoce a la Administración constituiría un abuso de derecho o, como sostiene la parte actora, un verdadero supuesto de desviación de poder, al implicar el ejercicio de potestades administrativas para fines distintos de los fijados por el Ordenamiento jurídico» (STS de 10 de febrero de 1997, Ar. 1137).

Así pues, el TS confirma la sentencia de instancia (ya que la medida decretada por el Ayuntamiento no reporta beneficio alguno a los usuarios... y por no justificarse en virtud del interés público) anulando la decisión administrativa.

Por tanto, la indemnización, como garantía frente al ius variandi, puede ser una garantía insuficiente, cuando lo procedente sea la anulación de la decisión administrativa.

Tampoco puede invocarse el ius variandi por la Administración a efectos de legitimar la sustitución de la parte acreedora del contrato (mediante comunicación al contratista de que los pagos se realizarán a una sociedad anónima indicada en aquélla). La STS de 14 de enero de 2000, Ar. 1574, entiende este supuesto como una novación no autorizada por la contraparte y por tanto nula.

\section{C) La segunda garantía del contratista: la indemnizatoria y sus límites}

Como ya nos consta, frente al ius variandi se sitúa la compensación del contratista. Dicen en este sentido los clásicos del Derecho administrativo: frente a la modificación unilaterial del contrato por la Administración «lo que queda al concesionario es la facultad de pedir la rescisión o una indemnización de daños y perjuicios»» ${ }^{11}$.

Algunas veces no será fácil descubrir la identidad real del supuesto planteado. Podrá ocurrir que, aunque deba indemnizarse al contratista, la

1 C. GARCíA OvIEDo, La concesión de servicio público, Sevilla, 1924, p. 62 citando a su vez a JèzE. 
compensación deba hacerse aplicando simplemente aquella regla elemental según la cual el contratista tiene derecho al abono de la obra realmente ejecutada (en el contrato de obras lógicamente).

En este sentido, la STS de 6 de noviembre de 1997, Ar. 8002, reconoce al contratista el derecho al pago frente a la orden de la dirección de obras de utilización de zahorras en el relleno de pavimentación de aceras. La estipulación en los pliegos de esta posibilidad consiguió evitar la aplicación del principio del riesgo y ventura.

Por otra parte, en cuanto a los límites de la compensación económica en favor del contratista, téngase en cuenta que la LCAP deja claro que en el supuesto de reducción o supresión de obras, el contratista no tendrá derecho a reclamar indemnización alguna (art. 146.1 de la LCAP).

Por su parte, la jurisprudencia añade que «las modificaciones del contrato que no sean sustanciales» impedirán el ejercicio de los derechos del contratista a ser compensado por aquéllas (STS de 21 de enero de 2000, Ar. 1230).

\section{D) La tercera garantía: la resolución del contrato}

Junto a las anteriores, otra regla importante es aquella a cuyo tenor las modificaciones en el contrato que impliquen alteraciones por una cuantía igual o superior a un 20 por 100 del precio primitivo del contrato facultan a las partes a la resolución del contrato «de obras» [STS de 29 de enero de 1999, Ar. 1498; art. 149.e) de la LCAP].

Este tipo de modificaciones originan en efecto la «facultad» de resolución del contrato y devolución de la fianza, aunque no necesariamente la indemnización de daños y perjuicios «por no apreciarse incumplimiento de la Administración» (STS de 27 de octubre de 1997, Ar. 7632 FJ 4. ${ }^{\circ}$ ).

\section{EL PRINCIPIO DE ENRIQUECIMIENTO INJUSTO}

Dentro de las técnicas correctoras de los desequilibrios patrimoniales se encuadra el enriquecimiento injusto o sin causa, el cual se ha considerado jurisprudencialmente como manifestación del principio de buena fe ${ }^{12}$.

12 STS de 29 de enero de 1993, Ar. 426, citando una STS de 12 de junio de 1984. 
También presupone por tanto este principio la aparición de algún elemento sobrevenido que altera el régimen inicial del contrato y que debe ser compensado en favor del contratista. De ahí que la jurisprudencia afirme que aquél se entienda dentro de la tendencia que viene «suavizando la aplicación del principio de inalterabilidad contractual» de modo que «la aplicación del principio que veda un enriquecimiento injusto posibilita el reconocimiento en los contratos de obras de reclamaciones por exceso sobre el proyecto que hubiere efectivamente ejecutado como consecuencia de órdenes de la Administración» (STS de 15 de junio de 1999, Ar. 6449).

También consigue el principio del enriquecimiento injusto recomponer el equilibrio económico de un contrato de obras roto como consecuencia de una "variación de precios de los ligantes asfálticos», ya que de lo contrario se produciría un enriquecimiento injusto a favor de la Administración que rompería el equilibrio económico-financiero (STS de 17 de diciembre de 1997, Ar. 282).

Por tanto, el principio del enriquecimiento sin causa no se aplicará cuando deba aplicarse el principio de riesgo y ventura, no siendo siempre fácil dilucidar qué principio es procedente en el caso concreto:

«No es aplicable (el principio del enriquecimiento sin causa) a los beneficios y pérdidas que puedan resultar para una parte de la ejecución de un contrato, que constituyen el riesgo propio de la actividad negocial» (STS de 15 de noviembre de 1994, Ar. 8514).

Por contrapartida, el enriquecimiento injusto podrá servir para matizar o limitar una aplicación rigurosa del principio de riesgo y ventura (así, la STS de 15 de junio de 1999, Ar. 6449).

Interesante es cómo esta doctrina del enriquecimiento injusto resuelve el problema de garantizar debidamente al contratista cuando dicho problema no se resuelve aplicando el mecanismo de la revisión de precios.

Esto ocurre, por ejemplo, cuando dicha revisión no está pactada en el contrato (y por tanto no puede invocarse, ya que dicha revisión no procede ex lege), pero es de justicia compensar de alguna forma al contratista evitando al mismo tiempo una indeseada aplicación del riesgo y ventura. En este sentido, la STS de 29 de enero de 1993, Ar. 426, aplicando aquél, decreta la necesidad de compensar al contratista por los gastos que le ocasionó la adaptación «del proyecto arquitectónico a la realidad física del 
edificio» (sin ignorar que en este caso la Administración había autorizado las obras nuevas).

Asimismo, se declara la ineficacia de la revisión de precios cuando «concurren hechos que escapen a las previsiones normativas establecidas al efecto produciendo un gran desequilibrio económico en la relación contractual». En estos casos «procede aplicar la doctrina del riesgo razonablemente imprevisible» (STS de 26 de diciembre de 1990, Ar. 9646).

Campo abonado para la aplicación del enriquecimiento injusto serían (según una STS de 29 de enero de 1993, Ar. 426) aquellos casos de alteraciones no sustanciales del proyecto de obras siempre que no puedan compensarse de otra forma.

\section{EL RIESGO IMPREVISIBLE}

$\mathrm{El}$ «riesgo imprevisible» consigue, igualmente, compensar al contratista. Se aplicará cuando aparezca un riesgo que no pudo ser previsto al tiempo de celebrarse el contrato, alterándose sustancialmente las condiciones de ejecución del contrato, de manera que la prestación pactada resulta mucho más onerosa para una de las partes de la que inicialmente había podido preverse, lo que permite la rescisión del contrato y en su caso la indemnización de ese mayor coste que no debe ser asumido por la parte a quien el suceso o acontecimiento imprevisible ha perjudicado (STS de 30 de abril de 1999, Ar. 4691).

En una STS de 19 de enero de 1998, Ar. 322, el Supremo precisa que, para proceder al reequilibrio económico, es menester que las circunstancias desencadenantes del desequilibrio contractual, además de ser imprevisibles, sean producidas sin culpa en los contratantes:

«Pues bien, en el supuesto actual de referencia, la sucesiva elevación del precio de un producto utilizado necesariamente en la obra contratada, como es el ligante asfáltico, si bien no determinó la imposibilidad de ejecución de la obra -imposibilidad no deseada por ninguna de las partes concurrentes- sin embargo dicha excesiva elevación de precio del aludido producto hizo sumamente oneroso el cumplimiento para el contratista de las prestaciones a las que se había obligado, pues los nuevos precios al alcanzar elevaciones razonablemente imprevisibles, aun empleando una especial diligencia, vinieron a modificar la estructura de los costes de la obra, con lo que es evidente la producción de una ruptura del primitivo equilibrio económico contractual.» 


\section{EL FACTUM PRINCIPIS}

Se ha definido jurisprudencialmente el factum principis como la adopción de una medida político-económica al margen del contrato que produce un desequilibrio económico en el contratista (STS de 12 de julio de 1995 Ar. 5888; puede verse, igualmente, la STS de 10 de junio de 1998, Ar. 4865).

Además, para que se derive indemnización es necesario: que el perjuicio sea evaluable, que haya situación de imprevisibilidad y, finalmente, que exista relación de causalidad entre la medida adoptada y el perjuicio ocasionado (STS de 12 de julio de 1995, Ar. 5888).

Se insiste en otra jurisprudencia en la necesidad de acreditar la existencia de «perjuicios», para que pueda derivarse responsabilidad por factum principis ${ }^{13}$.

La consecuencia de identificar una situación tal es, pues, que la Administración debe correr con los perjuicios derivados del factum principis.

En el caso que enjuicia esta STS de 12 de julio de 1995, Ar. 5888, se trataba, en particular, del desequilibrio económico que produjo una diferencia de cambio del dólar USA en operación de exportación al Ecuador comprendida en el Convenio de Refinanciación con dicho país sobre el régimen económico de la licencia de exportación del particular.

Un ejemplo interesante de aplicación del factum principis, junto a otras técnicas de compensación en favor del contratista, puede ser la STS de 19 de enero de 1998, Ar. $322{ }^{14}$.

En la presente sentencia debe dilucidarse si ha de compensarse al contratista ante una subida de precios de los productos derivados del petróleo que incrementa la onerosidad del asfaltado de una carretera que ha sido contratado por la Administración. El TS concluye que procede la «compensación jurídica en favor del contratista» y para ello, de forma interesante, indaga qué principio jurídico es aplicable.

Frente a la posibilidad de aplicar la figura de la revisión de precios, el TS sostiene que en este caso «la revisión de precios deviene ineficaz, por

\footnotetext{
13 De ahí que no se conceda indemnización por la STS de 24 de mayo de 1994, Ar. 1737, a pesar de que la modificación, hecha por la Autoridad Aeroportuaria, de «salidas nacionales» por «entradas nacionales» "fue un factum principis».

14 Puede verse, igualmente, la STS de 9 de marzo de 1999, Ar. 2888.
} 
concurrir otros hechos que escapan a las previsiones normativas establecidas al efecto, produciendo con ello en la relación jurídico-contractual que vincula a las partes un desequilibrio económico de tal entidad y naturaleza que el cumplimiento por el contratista de sus obligaciones derivadas de ella (es) excesivamente oneroso para el mismo, el cual razonablemente no pudo precaver, incluso empleando una diligencia fuera de las normas en este tipo de contrataciones» ${ }^{15}$.

De ahí que el TS afirme la necesidad de proceder a un nuevo equilibrio económico «en cuanto no hayan sido cubiertos a través de la figura jurídica de la revisión de precios».

El TS se apoya, entonces, a efectos de conceder la indemización en favor del contratista, en el «factum principis» (y las compensaciones que conlleva) y en el «riesgo razonablemente previsible» (puede verse supra la referencia hecha a esta sentencia en torno al riesgo imprevisible).

\section{LA REVISIÓN DE PRECIOS}

\section{A) Definición y presupuestos de la revisión de precios}

«Sabido es que la revisión de precios es un sistema establecido en aras al principio de equilibrio financiero para compensar los desajustes que en ese aspecto la realidad socio-económica con su falta de estabilidad les causa. La jurisprudencia ha venido insistiendo sobre su carácter excepcional en cuanto pugna con una serie de principios fisicos de la contratación administrativa, como son el de riesgo y ventura, el de precio cierto, el de inmutabilidad del contrato ex lege; y sobre la exigencia que ello comporta, de estimarse las estipulaciones que la contengan con un espíritu restrictivo, excluyendo interpretaciones analógicas o ampliaciones no previstas expresa y categóricamente» (STS de 30 de enero de 1995, Ar. 317, con otras referencias jurisprudenciales; puede seleccionarse igualmente la STS de 18 de marzo de 1999, Ar. 2904 FJ 3. ${ }^{\circ}$ o STS de 6 de mayo de 1992, Ar. 4238 FJ $2 .^{\circ}$ ).

La revisión de precios es expresión del principio de equilibrio financiero de la concesión, de modo que «la mayor onerosidad sobrevenida debe ser compartida por la Administración y el concesionario, bien resulte de una modificación del objeto del mismo, bien provenga de aconteci-

15 Igualmente, STS de 26 de diciembre de 1990 Ar. 9646. 
mientos imprevistos, previstos o previsibles en el momento de celebrar el contrato» (STS de 14 de diciembre de 1994, Ar. 9825).

Según la LCAP, dicha revisión presupone que el contrato se hubiere ejecutado en el 20 por 100 de su importe y haya transcurrido un año desde su adjudicación, de modo que ni el porcentaje del 20 por 100 , ni el primer año de ejecución, pueden ser objeto de revisión.

Además, en ningún caso procederá la revisión de precios en los contratos cuyo pago se concierte mediante el sistema de arrendamiento financiero o de arrendamiento con opción a compra (art. 103.2 de la LCAP).

La revisión se detallará en los pliegos de cláusulas administrativas particulares. «La revisión de precios procede conforme a las cláusulas convenidas» (STS de 8 de octubre de 1996, Ar. 7584) debiendo éstas expresarse y convenirse dentro de los límites establecidos por las pertinentes disposiciones legales cuando exista tal regulación (STS de 3 de julio de 1997, Ar. 5718; STS de 29 de junio de 1995, Ar. 5020) ${ }^{16}$.

«Conforme a las cláusulas convenidas» suele pactarse la revisión de precios el día 1 de enero de cada año, aplicándose la fórmula polinómica que figura en el anexo de los propios Pliegos (informa por ejemplo STS de 15 de diciembre de 1994, Ar. 10394 y STS de 25 de enero de 1999, Ar. 1500; STS de 20 de diciembre de 1996, Ar. 9532).

En la práctica jurisprudencial es determinante observar, a efectos de decretar o no la revisión de precios, si ha existido retraso o demora por parte del contratista (o si en cambio dicho retraso no le es imputable).

De manifestarse dicho retraso, el contratista pierde derecho a la revisión de precios, en aplicación del artículo 6 del Decreto-ley 2/1964, de 4 de febrero, sobre revisión de precios en los contratos del Estado y organismos autónomos (STS de 21 de enero de 1992, Ar. 628) ${ }^{17}$.

\footnotetext{
${ }^{16}$ Para el sistema de revisión y su régimen jurídico pueden verse los artículos 104 a 108 de la LCAP (STS de 16 de diciembre de 1998, Ar. 761).

17 La disposición derogatoria única 1.e de la LCAP derogó el presente Decreto-ley, así como sus disposiciones complementarias, manteniendo su vigencia con carácter reglamentario en cuanto no se opongan a dicha Ley, para todos los contratos sujetos a revisión.
}

En todo caso, esta norma no es aplicable a los contratos de prestación de servicios (STS de 27 de noviembre de 1998, Ar. 300, basándose en que aquél surte efectos exclusivamente en los contratos de obras, salvo que exista pacto expreso de las partes en tal sentido, con otras referencias jurisprudenciales). Las razones de esta inaplicación son explicadas en la STS de 18 de octubre de 1994, Ar. 7523, en esencia la propia configuración del contrato de gestión de servicios públicos como 
También pierde dicho derecho si el contratista solicitó una "prórroga» para la terminación de las obras objeto del contrato (véase el citado art. 6 in fine; un ejemplo: STS de 25 de junio de 1998, Ar. 4560).

Este sistema podrá llevar consigo la necesidad de descubrir cuál es el plazo real de ejecución del contrato a efectos de observar si el contratista tiene derecho o no a la revisión de precios cuyo presupuesto es la ejecución del contrato dentro del plazo pactado (puede seleccionarse la STS de 24 de mayo de 1994, Ar. 3906).

No obstante, la jurisprudencia exige que, además del retraso, éste sea «achacable» al contratista, en términos de la STS de 30 de enero de 1995, Ar. 317. De ahí que el fallo conceda al contratista la revisión de precios ya que el retraso se produjo por causa que no le fue imputable ${ }^{18}$.

Esta regla encuentra especial sentido cuando el retraso se imputa a la propia Administración (puede verse la STS de 1 de junio de 1993, Ar. 4511) o en casos de fuerza mayor siempre que se pruebe debidamente la relación causa-efecto (STS de 7 de febrero de 1994, Ar. 1011), ya que en todo caso la revisión de precios presupone el cumplimiento de las obligaciones asumidas por el contratista (STS de 22 de septiembre de 1997, Ar. 7315).

\section{B) Delimitación de la revisión de precios con otros supuestos, en especial el riesgo y ventura del contratista}

Muchas veces no es fácil identificar realmente el supuesto y si debe aplicarse la revisión de precios o, en cambio, cualquier otro principio rector de los derechos y obligaciones de las partes contratantes.

Así, no procederá la revisión de precios, cuando proceda simplemente el abono adicional de la prestación realizada. En este sentido, conforme a una STS de 7 de junio de 1997, Ar. 5025, «los conceptos de ampliación de servicios y servicios extraordinarios no pueden ser incluidos en la revisión (...) ya que, caso de prestarse eventualmente los expresados servi-

tracto sucesivo frente al contrato de obras, como contrato de resultado. En estos casos, la revisión de precios procederá simplemente conforme a lo estipulado en la cláusula contractual revisoria (por ejemplo, junto a la Sentencia citada, STS de 22 de mayo de 1997, Ar. 3939).

En cambio, es aplicable a los contratos de arrendamientos de obras y servicios - de vigilancia y detección de desperfectos, inventario y auscultación y vigilancia especial de las estructuras resistentes (...) - (STS de 19 de febrero de 1999, Ar. 2231).

18 Igualmente, STS de 3 de mayo de 1996, Ar. 3851; STS de 3 de mayo de 1996, Ar. 3850; STS de 29 de marzo de 1994, Ar. 2402. 
cios mejorados o extraordinarios, se retribuirían adicionalmente conforme a lo previsto en las cláusulas 12 y 19 del Pliego, conforme a cuantías actualizadas y revisadas».

Pero el supuesto más interesante es, evidentemente, el de deslindar a la luz de la casuística jurisprudencial entre el principio de riesgo y ventura del contratista y la revisión de precios (respectivamente, arts. 98 y 103 de la LCAP respecto de todo tipo de contrato administrativo).

En primer término, la revisión de precios exigirá que el contratista acredite el desequilibrio económico producido. De ahí que una STS de 11 de abril de 2000, Ar. 3987, deniegue aquélla por ausencia de prueba del contratista.

De ahí que no será objeto de una compensación económica (encajando también el caso dentro del riesgo y ventura del contratista) el supuesto en que, para la ejecución de la obra, se precisó «un aumento de los husillos a limpiar (en el marco de un contrato de gestión de servicio público de limpieza de alcantarillado)», cuando dicho aumento no produjo ningún incremento de personal, de medios o de costes que justifique la revisión de precios que se discute en este proceso" por no afectar al equilibrio económico del contrato (STS de 22 de mayo de 1997, Ar. 3939).

El criterio es, pues, que no todo aumento de precios será compensado al contratista (STS de 15 de diciembre de 1994, Ar. 10394 y art. 4 del citado Decreto-ley 2/1964).

Por contrapartida, si se trata de simples «obras accesorias», de proceder la revisión de precios ésta afectará tanto a las obras objeto del contrato como a aquellas obras accesorias siguiendo el criterio de que lo accesorio sigue lo principal (STS de 11 de marzo de 1996, Ar. 2819).

También debe someterse a debido análisis una posible cláusula contenida en los pliegos a cuyo tenor procederá la revisión de precios «cuando concurran aumentos legalmente autorizados» debiéndose entender (STS de 23 de mayo de 1995, Ar. 3810) que los aumentos de precios ocasionados por la subida del carburante o de los salarios de personal no están condicionados a una previa autorización administrativa, ya que más bien es la previsión legal de dichos aumentos la causa misma de la revisión de precios.

En esta línea, la STS de 18 de marzo de 1999, Ar. 2904, se apoya, para denegar la revisión de precios, en el hecho de que los conceptos sobre los 
que se reclama aquélla no han sido autorizados por la Administración, «al no contar además con dotación presupuestaria suficiente, por lo que no puede ser impuesta por los concesionarios a la Administración, que es la única que tiene facultades para imponer mejoras en la prestación de los servicios conforme al artículo 19 del Pliego de Condiciones del contrato"».

\section{DERECHOS Y OBLIGACIONES DE LAS PARTES CONTRATANTES EN EL MOMENTO DEL PAGO DEL PRECIO Y DEL INCUMPLIMIENTO CONTRACTUAL}

\section{A) El pago de la prestación realmente realizada}

La garantía fundamental del contratista es el pago del precio (art. 99 de la LCAP) ${ }^{19}$.

El contratista tiene derecho al abono de la prestación realizada y con arreglo al precio convenido (art. 99.1 de la LCAP).

El pago hecho por la Administración podrá hacerse sin perjuicio de la posibilidad de aquélla de repetir el pago frente a otra Administración que considere responsable del pago (STS de 25 de noviembre de 1995, Ar. 8345).

Por su parte, el contratista tiene derecho a la transmisión de los derechos de cobro (art. 100 de la LCAP; véase la STS de 12 de marzo de 1992, Ar. 2124: «la Administración no puede desconocer el derecho de crédito adquirido frente a ella», a efectos de negarse al pago de las certificaciones).

La jurisprudencia deja claro que el contratista tiene derecho a cobrar las obras «realmente ejecutadas» (STS de 7 de febrero de 1994, Ar. $1010^{20}$ ).

Los excesos de obra autorizados por la Administración conllevan el pago de este tipo de obras (STS de 7 de abril de 1994, Ar. 2996): «la Sala

\footnotetext{
${ }^{19}$ Para este enfoque, por todos, R. C. Barra, Contrato de obra pública, Buenos Aires, sin fecha, pp. 892 y ss.

${ }^{20}$ En este sentido, la STS de 20 de abril de 1999, Ar. 4638, expresiva del susodicho principio, cifra, como cantidad a abonar al contratista, la diferencia entre el total importe de las obras realizadas conforme al proyecto de y de los otros trabajos no incluidos en éste pero de ejecución necesaria, y el importe de la certificación pagada. Puede verse también la STS de 13 de abril de 1992 Ar. 3479.
} 
entiende que las obras litigiosas fueron autorizadas y, como ya se ha indicado, que tuvieron su origen en necesidades nuevas o causas técnicas no previsibles al tiempo de elaborar el proyecto, por lo que, con base en los preceptos legales antes indicados, procede declarar el derecho de la entidad recurrente al abono de las mismas, cuyo importe no ha sido cuestionado».

De ahí también que la ejecución parcial de la obra lleva consigo el abono de la parte ejecutada (STS de 26 de enero de 1980, Ar. 135).

Además, tiene el contratista derecho a percibir abonos a cuenta por el importe de las operaciones preparatorias de la ejecución del contrato (art. 99.1 de la LCAP; puede verse también el art. 99.4 de la misma LCAP respecto del embargo de dichos abonos).

La Administración tendrá la obligación de abonar el precio dentro de los dos meses siguientes a la fecha de la expedición de las certificaciones de obras (o de los demás documentos que acrediten la realización total o parcial del contrato).

Conviene recordar que las certificaciones de obras "constituyen un título de crédito en favor del contratista por la realización de las obras realmente ejecutadas, a cambio de un precio»" (STS de 15 de junio de 1999, Ar. 6449) ${ }^{21}$.

\section{B) Responsabilidades en caso de demora}

\section{B.1) Demora del contratista en la ejecución de las obras}

Si es el contratista quien demora la ejecución del contrato (respecto del plazo estipulado en el contrato) la Administración puede optar o bien por la resolución del contrato o bien por la imposición de penalidades diarias en proporción de 20 por cada 100.000 pesetas (o penalidades distintas en el pliego de cláusulas generales). La misma facultad se refiere al incumplimiento de plazos parciales o a la inejecución parcial (art. 94 de la LCAP).

En caso de resolución del contrato se exige audiencia en favor del contratista (y dictamen del Consejo de Estado, en caso de oposición de aquél; art. 96 de la LCAP) aunque la jurisprudencia —como es sabido — tiende

${ }^{21}$ Sobre las certificaciones de obras, por todos, P. OLIVERA MASSO, El régimen juridico de las certificaciones de obra tras la Ley de Contratos de las Administraciones Públicas, Madrid, 1995. 
a flexibilizar el alcance de estos presupuestos procedimentales o formales, cuando no se han cumplido, observando si es posible una interpretación no rigorista que evite la anulación del contrato ${ }^{22}$.

El contratista es además responsable de los daños y perjuicios que se causen a terceros como consecuencia de la ejecución del contrato (art. 97 de la LCAP).

\section{B.2) Demora de la Administración en el pago de las certificaciones}

La demora de los pagos de las certificaciones de obras origina el pago de intereses con el incremento de un 1,5 puntos en favor del contratista (art. 99.4 de la LCAP; véanse también los arts. 110.4 y 147.3 de la LCAP, así como - para el contrato de suministro- los arts. 185 y ss.).

La jurisprudencia deja claro que los perjuicios ocasionados por la demora del pago de las certificaciones de obra originan responsabilidad en favor del contratista con intereses de demora (STS de 20 de octubre de 1993, Ar. 7909; STSJ de Canarias de 19 de diciembre de 1997, rec. 1284/1995).

Si la demora de la Administración en el pago fuese superior a cuatro meses, el contratista podrá proceder a la suspensión del cumplimiento del contrato (previa comunicación a la Administración; art. 99.5 de la LCAP).

Si la demora en el pago fuese superior a ocho meses, el contratista podrá proceder a la resolución del contrato y a la reclamación de daños y perjuicios (sobre dicha reclamación puede verse la STS de 27 de abril de 1998, Ar. 3365).

\section{B.3) Demora de la Administración en la iniciación, recepción, liquidación del contrato o pago por estos conceptos}

Es preciso empezar recordando el régimen legal de la LCAP sobre el particular. En general, es decir en las disposiciones válidas para todo tipo de contratos, se prevén las fases siguientes (art. 110):

\footnotetext{
22 Puede por ejemplo verse la STS de 27 de abril de 1998, Ar. 3364. Igualmente, la STS de 10 de julio de 1997 Ar. 5928, respecto de la «notificación al contratista» con el defecto formal de no indicación de los recursos procedentes. «Toda notificación defectuosa es expresión de un incorrecto actuar de la Administración y son inválidas cuando real y efectivamente hayan producido indefensión al interesado o hayan limitado el ejercicio de sus derechos» (STS de 28 de abril de 1992, Ar. 4115, FJ 2, párrafo 4).
} 
- Entrega de las obras una vez transcurre el plazo de ejecución fijado en los pliegos.

- Acto formal o positivo de recepción por parte de la Administración en el plazo de un mes desde dicha entrega.

- Liquidación del contrato en un mes desde el acta de recepción, sin perjuicio de los plazos de garantía que se estipulen.

- Intereses en favor del contratista en caso de demora del pago del saldo de la liquidación incrementado un 1,5 por 100 .

Y básicamente en el caso del contrato de obras las fases son en cambio las siguientes (art. 142 de la LCAP):

- Iniciación de la ejecución del contrato tras el acta de comprobación del replanteo.

- Entrega de las obras una vez transcurre el plazo de ejecución fijado en los pliegos.

- Acto formal o positivo de recepción por parte de la Administración en el plazo de un mes desde dicha entrega.

- Certificación final de las obras ejecutadas a cuenta de la liquidación del contrato en el plazo de dos meses a partir de dos meses desde la recepción.

- Comienzo del plazo de garantía después de la recepción de las obras estipulado en los pliegos.

- Liquidación del contrato quince días antes del término del plazo de garantía siemrpe que el informe sobre el estado de las obras fuera favorable.

Pues bien, la jurisprudencia deja claro el derecho indemnizatorio del contratista frente a la Administración en los casos siguientes:

- En caso de no recepción de las obras - culpable por parte de la Administración-(STS de 24 de noviembre de 1997, Ar. 8017, declarando el derecho del contratista a ser indemnizado por los perjuicios ocasionados). 
- En caso de daños causados por la Administración como consecuencia de retrasos en la ejecución de las obras (STS de 27 de noviembre de 1998, Ar. 302).

- En caso de demora en el pago después de la recepción de las obras y la liquidación (STS de 1 de febrero de 1994, Ar. 1001).

Por otra parte, téngase en cuenta que este régimen legal modifica en parte el contenido en el Reglamento General de Contratación. Interesaría destacar que, en caso de exigirse una intimación por parte del contratista para que puedan devengarse derechos indemnizatorios en su favor (puede verse el art. 172 del citado RGC) la STS de 30 de enero de 1995, Ar. $317^{23}$, recogiendo una amplia corriente jurisprudencial, deja claro que «la intimación es requisito meramente formal que pone en marcha la actuación administrativa, pero no requisito sustancial condicionante de la constitución en mora de la Administración; pero la finalización del plazo de los nueve meses a que se refiere el artículo 172 del RGC actúa ope legis según el principio dies interpellat pro homine, de tal modo que el devengo de intereses se produce ya desde el día siguiente a ese transcurso, porque ya ha incurrido en mora (Sentencia de 22 de noviembre de 1994, RJ 1994, 8642)».

\section{C) La idea de reparación integral y el beneficio industrial}

Para terminar esta cuestión conviene matizar, a la luz de la jurisprudencia de la jurisdicción contencioso-administrativa, la idea de reparación integral que rige sobre el particular. Conlleva aquélla una indemnización tanto del daño emergente como del lucro cesante o beneficio industrial.

El «lucro cesante» merecería un comentario aparte con apoyo de una ilustrativa STS de 20 de abril de 1999, Ar. 4641:

«Al considerar el artículo 148 del Reglamento de Contratación que los perjuicios indemnizables al contratista sean los efectivamente sufridos por éste, no quiere decir por eso que queden excluidos del concepto los que impliquen un lucro cesante, si éste es real y efectivo, sino, simplemente, que al igual que los constitutivos de un daño emergente esté perfectamente acreditada y constatada la realidad de su existencia, de modo que no alcancen solamente la mera calificación de eventuales o posibles, siendo aquélla la idea a la que responde la noción de efectividad. Por eso, siendo incontestable que en determinados momentos de la ejecución del contrato de obra objeto de esta litis, dicha obra permaneció apla-

${ }^{23}$ Igualmente, STS de 7 de abril de 1994, Ar. 2996. 
zada por causa imputable a la Administración, según se afirma en la sentencia recurrida, resulta evidente también que en ese tiempo la empresa no pudo disponer de aquel 5 por 100 de las certificaciones de obra que en otro caso le hubiese entregado, lo que constituye un perjuicio consistente en un lucro que, aunque cesante, resulta perfectamente calificable de real y efectivo y además también claramente valorable, por aplicación de las sumas que resultan del interés legal del dinero durante los respectivos períodos de retención causados por el mencionado aplazamiento atribuido a la responsabilidad de la Administración» ${ }^{24}$.

No obstante, común será que no se justifique «la presencia de factores que pudiesen determinar» la existencia de un beneficio industrial (STS de 18 de marzo de 1999, Ar. 2904, FJ 3. ${ }^{\circ}$ in fine).

En todo caso (puede verse la STS de 24 de septiembre de 1999, Ar. 8063) la resolución de un contrato por parte de la Administración lleva consigo una indemnización que debe extenderse a todo lo que acredite (el contratista) haber sufrido como consecuencia directa del retraso en la ejecución del contrato actualizando aquellas partidas que por ser deudas de valor no dineraria, por la depreciación constante de la moneda, deduciéndose en su caso el lucro cesante y el daño emergente de datos reales y convincentes.

Junto al presupuesto de la reparación integral, se plantea el problema de la imputación de la responsabilidad para que ésta pueda derivarse. En materia de incumplimentos es preciso dilucidar en el caso concreto a quién deben imputarse dichos incumplimentos, si a la Administración o al contratista, a efectos de exigir la reclamación de los daños que hubieran podido ocasionarse (puede verse la STS de 22 de septiembre de 1999, Ar. 7927, o STS de 18 de septiembre de 1997, Ar. 6597; STS de 23 de marzo de 1998, Ar. 2239; art. 113.3 de la LCAP).

O a ambos, como ocurre en la STS de 22 de julio de 1987, Ar. 7668, procediendose a un reparto de responsabilidades.

En todo caso, siguiendo la STS de 16 de mayo de 1997, Ar. 3932, las causas de resolución contractual han de merecer una interpretación restrictiva y ceñida a aquellas previstas expresamente en la LCAP.

A veces, para la resolución por incumplimiento de la Administración se ha requerido que aquél sea "grave», de naturaleza sustancia, y responder al incumplimiento de obligaciones contractuales (STS de 29 de mayo de 2000, Ar. 5746).

${ }^{24}$ Asimismo, puede verse sobre el lucro cesante la STS de 9 de diciembre de 1997, Ar. 9350, indemnizándose al contratista por los beneficios que hubiera podido obtener de haberse respetado por la Administración el tiempo de duración del contrato. 


\section{GARANTÍAS Y FIANZAS}

Procederá la devolución de la garantía «aprobada la liquidación del contrato ${ }^{25}$, si no resultaren responsabilidades que hayan de ejercitarse sobre la garantía y transcurrido el plazo de la misma» (art. 47 de la LCAP).

De este modo, la STS de 4 de julio de 1984, Ar. 4660, decreta la no devolución de la fianza ante desperfectos sustanciales en la obra terminada.

En el supuesto de recepción parcial sólo podrá el contratista solicitar la devolución o cancelación de la parte proporcional de la garantía cuando así se autorice expresamente en el pliego de cláusulas administrativas particulares» (art. 47.2 de la LCAP).

La devolución o cancelación de las garantías procederá sin más demora transcurrido un año desde la fecha de terminación del contrato sin que la recepción formal y la liquidación hubieren tenido lugar por causas no imputables al contratista, siempre que no se hubieran producido responsabilidades (art. 47.3 de la LCAP; STS de 21 de octubre de 1998, Ar. 8654).

Si el contrato se resuelve por incumplimiento culpable del contratista, le será a éste incautada la garantía y deberá indemnizar a la Administración (art. 113.4 de la LCAP; puede por ejemplo verse la STS de 11 de junio de 1996, Ar. 5148, o la STS de 22 de noviembre de 1993, Ar. 8514).

Por contrapartida, si finalmente se comprueba que al contratista no le es imputable ninguna causa de incumplimiento que facultara a la Administración para ejercitar la facultad resolutoria se ordenará la devolución de la fianza (STS de 20 de abril de 1999, Ar. 4636).

La fianza garantiza los supuestos de incumplimiento sin perjuicio de exigir otras cantidades si el importe de los daños o defectos rebasan la cuantía de la fianza establecida». Por contrapartida, sólo se cubren las responsabilidades directamente derivadas de la contratación administrativa, no derivadas de la gestión de la contrata» (STS de 3 de febrero de 1998, Ar. 857).

En la jurisprudencia se reconoce en este sentido el derecho a la devolución de la fianza e indemnización por la demora en la no devolución (STS de 28 de enero de 2000 Ar. 1579; de 22 de abril de 1996, Ar. 3263; STS de marzo de 1998 Ar. 1881).

${ }^{25}$ En este sentido, puede verse la STS de 7 de febrero de 1994, Ar. 1010: la devolución de la fianza procede una vez se produzca la liquidación definitiva de las obras». 
Pero este derecho no se concede cuando el contratista no haya obrado con un mínimo de diligencia, ya que «dejaba las fianzas depositadas, teniendo que citarle la Administración para que pasase a recogerlas $(. .). »{ }^{26}$.

\section{LOS MECANISMOS DE COMPENSACIÓN DEL CONTRATISTA EN LOS CONTRATOS DE CONCESIÓN DE OBRAS PÚBLICAS CON EL EJEMPLO DE LAS AUTOPISTAS}

Se profundiza en el régimen jurídico que acaba de ser estudiado tomando como referencia el caso del contrato de concesión de obras públicas, al que no hemos hecho referencia hasta el momento. Tiene este contrato por objeto la realización de una obra obteniendo el adjudicatario el derecho a explotar la obra o el derecho a recibir un precio.

En las últimas reformas legislativas de la LCAP el contrato de concesión de obra pública ha venido mereciendo una regulación cada vez más precisa (arts. 130 de la LCAP de 1995 y de 2000) ${ }^{27}$.

Interesa una Sentencia del TS de 6 de junio de 1997, Ar. 5219, cuando en materia de autopistas sienta que la concesión se define como «explotación de una obra pública que tiene la naturaleza de concesión mixta, de servicio público y demanial, puesto que el concesionario para la prestación del servicio público está utilizando un bien de dominio público, y por ello, nos encontramos ante la concurrencia de una concesión demanial y otra de servicio público, admitida ya por numerosa jurisprudencia del Tribunal Supremo, Sentencias de 4 de julio de 1967 y de 20 de noviembre de 1969 (RJ 1967/2876), entre otras, en las cuales no se produce el denominado principio de atracción de las concesiones demaniales, sino que da lugar al fenómeno de accesoriedad concesional subordinando la concesión de dominio a la del servicio».

Esta doctrina podría ser completada con aquella otra contenida en la resolución de 26 de marzo de 1999 (JT 1999\1549), en la que el Tribunal Económico-Administrativo Central se ve en la necesidad de dilucidar si el contrato en cuestión era un contrato de obras públicas (quedando la empresa adjudicataria sujeta al Impuesto General sobre Tráfico de Empresas) o un contrato de concesión de obra pública (quedando exento

\footnotetext{
26 STS de 19 de febrero de 1996 Ar. 973.

27 En la jurisprudencia algunas menciones a esta figura se hacen en las SSTS de 2 de junio de 1982, Ar. 4180, de 7 de febrero de 1984, Ar. 782; de 18 de mayo de 1998, Ar. 3959 FD 3.
} 
de dicho Impuesto). De esta resolución interesa en este contexto el párrafo siguiente:

«La concesión, en la que el empresario asume el riesgo y el beneficio de la explotación de un servicio público, puede ser de obra pública, en la que el concesionario ha de realizar una construcción de tal carácter y se encarga de la explotación del servicio público que tal construcción propicia, o de simple explotación, cuando la obra no es necesaria o ya esté construida. Es por tanto algo diferente al mero contrato de obras. Ambos tienen en común el principio de riesgo y ventura en que se concreta la locatio operis, es decir se pretende en tales contratos un resultado contra un precio fijo o alzado, pero en el segundo cobra especial importancia la figura del contratista colaborador (...). Es importante tener en cuenta que, aunque la Administración concedente y el concesionario confluyen en la consecución del mismo fin, la primera conserva siempre la titularidad del servicio y el concesionario no puede considerar como propia la obra realizada por el hecho de asumir el derecho-obligación de la explotación del servicio público. Configurada la concesión de obra como un contrato específico tipificado en las leyes citadas, no puede desgajarse a efectos de su tributación, tanto más si se considera que la figura de la concesión está recogida expresamente en el vigente TR del Impuesto de Transmisiones Patrimoniales y Actos Jurídicos Documentados (...) que es aplicable al presente caso (...)».

Este régimen de concesión, según el cual el concesionario lleva a cabo la explotación a su riesgo y ventura, se ha aplicado fundamentalmente a obras hidráulicas (abastecimientos, producción de energía hidroeléctrica, etcétera ${ }^{28}$ ) y sobre todo a las autopistas de peaje aunque también es facti-

${ }^{28}$ El artículo 173 de la Ley 13/1996, de 30 de diciembre, de Acompañamiento a los Presupuestos para 1997, incorpora una modalidad específica de contrato de concesión de construcción, conservación y explotación de obras e infraestructuras hidráulicas. Según dicho artículo, las Administraciones Públicas podrán utilizar este contrato para la construcción, conservación y explotación de las obras e infraestructuras vinculadas a la regulación de los recursos hidráulicos, su conducción, potabilización y desalinización, y al saneamiento y depuración de las aguas residuales. La contraprestación al cesionario consiste en el derecho a percibir una tarifa que fija la Administración siguiendo ciertos criterios establecidos en el apartado seis de este mismo artículo (además, la Administración concedente, cuando existan razones de interés público, rentabilidad social o uso colectivo, podrá compensar al concesionario parte de la obra pública prevista, en los términos que en cada caso se establezcan en los correspondientes pliegos contractuales).

Finalmente, en el apartado tercero de dicho artículo 173 se establecen reglas especiales en cuanto a su régimen jurídico (el plazo de explotación de la obra será el previsto en cada pliego de cláusulas administrativas particulares, sin que pueda exceder en ningún caso de setenta y cinco años; la Administración podrá imponer al concesionario, en el contrato, que ceda a un tercero un porcentaje de la construcción de la obra que represente, al menos, un 30 por 100 del valor total de la misma (...); quedan exceptuados estos contratos de las reglas de la legislación de Contratos de las Administraciones Públicas donde se prevé la necesidad de crédito adecuado y suficiente para poder llevar a cabo la obra. En esta línea, en el supuesto de compensación por parte de la Administración al concesionario de parte de la obra pública prevista, se autoriza a que el pago se lleve a cabo de forma aplazada, en los términos fijados en el propio contrato de concesión.

Téngase también en cuenta que en la Ley 29/1985, de 2 de agosto, de Aguas (título VIII: «de las obras hidráulicas», título añadido por el artículo único.47 de la Ley $46 / 1999$, de 13 de diciembre) se define la obra hidráulica (art. 114) siendo su titularidad pública o privada (art. 115). 
ble, por ejemplo (según aporta la STSJ de Castilla y León, de 4 de junio de 1999, Sentencia n..$^{\circ}$ 531/1999) para la construcción y explotación de un aparcamiento subterráneo, etc.

El interés de este contrato de concesión de obras públicas está en buena medida en contribuir a la realización de funciones públicas mediante una financiación privada.

En el caso de las autopistas esta financiación privada son los peajes que ha de pagar el usuario por la utilización de la autopista. Pero lo más normal es que incluso en estos casos de financiación privada y posterior reembolso mediante peajes asistamos a modelos intermedios o mixtos de financiación, ya que lo propio es la existencia de algún tipo de garantía o préstamo por parte del sector público.

El papel del Estado consiste entonces en el otorgamiento de beneficios tributarios y económico-financieros, tales como avales, seguros de cambio, subvenciones a fondo perdido, anticipos reintegrables, bonificación de cuotas impositivas, etc.

El caso de las autopistas pone de manifiesto las insuficiencias tanto del sistema clásico o tradicional de contratación de obra y financiación pública pura (previsto en la Ley de Obras Públicas y en la Ley de Carreteras) como de un modelo puramente privado, según el cual la carga económica de la construcción y conservación de la obra tiene que ser asumida por el concesionario a cambio de un peaje o tarifa que pagan los usuarios ${ }^{29}$.

\footnotetext{
${ }^{29}$ Este último sistema, factible en tramos de gran rentabilidad económica, se revela dificilmente practicable en otro caso; de ahí el régimen de la Ley de 1972 y su característico modelo de beneficios fiscales.
}

En general, parece generalizarse el modelo público-privado, evitando sistemas puramente públicos o puramente privados, procurando más bien la convergencia entre ambos como modelo concebible para las infraestructuras en general a través de la mayor financiación privada para la realización de esta función pública que es la construcción de infraestructuras.

De ahí que la concepción clásica tanto en España como en otros Estados según la cual la construcción y mantenimiento de carreteras es una función pública, de modo que aquéllas son propiedad de los poderes públicos y se financian mediante medios públicos presupuestarios poniéndose a disposición de los ciudadanos en general, parece entrar en crisis en tiempos más recientes.

Junto a las limitaciones del sistema de financiación presupuestaria para afrontar los retos de construcción y conservación de infraestructuras que la sociedad demanda no pueden pasarse por alto las exigencias de convergencia impuestas por la Unión Europea y la política de evitar aumentar el déficit presupuestario que está en el fondo de esta apertura a cauces adicionales privados de financiación de infraestructuras.

Por el incremento de las fórmulas de financiación privada de infraestructuras apuestan también los fondos de la Unión Europea ya que, de cara al nuevo período de programación 2000-2006, se fo- 
Junto al caso referido de la Ley de autopistas de 1972, proliferan en los últimos años una variedad de fórmulas de colaboración de los particulares en la realización de obras públicas e infraestructuras ${ }^{30}$.

Pero, más que profundizar en todas estas cuestiones a la luz principalmente del actual Proyecto de Ley básica de financiación y gestión privada de infraestructuras públicas ${ }^{31}$, interesa en este trabajo estudiar aunque brevemente, y desde el punto de vista de los derechos y obligaciones de contratista y Administración en la ejecución del contrato de concesión de obras públicas, la Ley 8/1972, de 10 de mayo, de construcción, conservación y explotación de autopistas en régimen de concesión.

En principio, la Ley 8/1972 viene a ser una Ley especial donde se regulan los aspectos que particularmente plantean las concesiones de autopistas. Y es además aplicable la Ley de Contratos de las Administraciones Públicas. Como afirma la STS de 19 de febrero de 1999, Ar. 1526, «la Ley 8/1972 es de aplicación preferente a la construcción de autopistas en régimen de concesión, siendo supletoria la legislación de contratos de las $\mathrm{AAPP} \gg 32$.

mentan los proyectos con financiación mixta pasando a depender activamente la adjudicación de los fondos comunitarios de los recursos privados obtenidos. Esto provoca el interés por buscar cauces a través de los que puedan canalizarse las iniciativas privadas.

En el Derecho comparado es significativa la Ley alemana de 1994, de construcción y financiación de carreteras por agentes privados (Gesetz über den Bau und die Finanzierung von Bundesfernstraßen durch Private) la cual permite delegar estas funciones públicas en particulares concesionarios (puede verse el art. 1.2 y 3 de la citada Ley) después de realizar un concurso público. Según la Exposición de Motivos de esta Ley, es preciso abrir cauces de financiación privados ya que mediante presupuestos no es posible cumplir en un plazo razonable los distintos procesos que actualmente son necesarios. A estos efectos se permite a los particulares el cobro de peajes (Mautgebühren) por la utilización de las infraestructuras construidas bajo este sistema, los cuales son fijados por el Ministerio de Transportes (art. 3).

Juridicamente, todas estas formas a través de las cuales empieza a desarrollarse la intervención de los particulares en la realización de una función pública, como es la construcción de infraestructuras viarias, pueden explicarse genéricamente a través de la idea de «colaboración».

${ }^{30}$ Puede verse S. GonzÁlez-VARAS IBÁÑEZ, Los mercados de interés general: telecomunicaciones $y$ postales, energéticos y de transportes, Editorial Comares, Granada, 2001, con otras referencias bibliográficas.

31 Véase en detalle sobre todos estos temas, S. GonZÁleZ-VARAS IBÁÑEZ, Los mercados de interés general: telecomunicaciones y postales, energéticos y de transportes, Editorial Comares, Granada, 2001.

32 Igualmente, según la STS de 6 de junio de 1997 Ar. 5219, «las concesiones administrativas de construcción, conservación y explotación de autopistas se regirán peculiarmente por la Ley 8/1972, de 10 de mayo, y sus normas de desarrollo complementarias (es decir, el Decreto 215/1973) y con carácter supletorio por la legislación de contratos del Estado (...)». 
El artículo 2 de la Ley de autopistas afirma que las concesiones administrativas de construcción, conservación y explotación de autopistas se regirán por lo dispuesto en esta Ley y supletoriamente por la legislación de contratos de las AAPP.

Por eso, cuando «no resulta posible aplicar al presente caso la legislación especial de autopistas (...), pues ni la una ni el otro contempla el supuesto de daños indemnizables que se produzcan en la autopista en explotación (...)», «no cabe la menor duda que ante tal laguna legal será preciso acudir a la legislación supletoria, que está constituida por la Ley de Contratos del Estado y el Reglamento General de Contratación del Estado, vigentes en el momento en que acaecieron los hechos» (STS de 6 de junio de 1997 Ar. 5219) ${ }^{33}$.

En realidad, antes que la Ley de autopistas, hay que estar al Real Decreto correspondiente donde se adjudica la concesión administrativa para la construcción, conservación y explotación de la autopista de peaje, por ser esta norma donde se prevé el régimen jurídico de la sociedad concesionaria (plan de realización de obras, garantías, préstamos, remuneración, tarifas iniciales y revisión de tarifas, responsabilidad patrimonial, período de la concesión) ${ }^{34}$.

Desde el punto de vista del equilibrio económico financiero interesa destacar:

- Primero, los artículos 11 a 15 de la Ley de autopistas donde se prevé un abanico de beneficios tributarios y financieros de entre los cuales la Administración puede elegir aquellos que en cada momento sean necesarios o convenientes para promover la construcción de una autopista concreta.

33 De ahí que el Tribunal Supremo en este caso concluya que «los daños derivados de fuerza mayor (inundaciones) no son de cuenta del contratista (Autopista Vasco-Aragonesa Concesionaria, S. A.) y éste tiene derecho a indemnización» (STS de 6 de junio de 1997, Ar. 5219; puede verse también la STS de 9 de diciembre de 1998, Ar. 10464).

34 Como estos mismos Reales Decretos precisan, en aquellos puntos no señalados específicamente en ellos mismos serán de aplicación la Ley 8/1972, de 10 de mayo, la Ley de Contratos de las Administraciones Públicas, las prescripciones de los pliegos de cláusulas particulares y de bases del concurso (aprobadas por orden ministerial), las del pliego de cláusulas generales aprobado por Decreto, así como el Decreto correspondiente de organización y funcionamiento de la Delegación del Gobierno en las sociedades concesionarias de autopistas nacionales de peaje. Lógicamente, el Decreto de adjudicación de la concesión supone una concreción del régimen legal a un caso concreto.

Finalmente, pueden tenerse en cuenta las reglamentaciones "de servicio» de la autopista de peaje donde se regula detalladamente la circulación por la autopista (precisando el Reglamento General de Circulación), la vigilancia del tráfico y transporte, el personal, el régimen de reparación de los daños causados en la autopista, los servicios al usuario y los peajes y tarifas. 
- Segundo, la fijación de las tarifas y peajes. Es ésta una pieza nuclear de la financiación de las concesionarias y parte de la oferta que se somete a concurso por parte del licitador interesado, quien realiza, como es lógico, un cálculo basado en distintos parámetros económicos, tales como principalmente el coste y dificultad de construcción de las obras, los años de amortización o el recorrido o volumen previsible de circulación, fijándose dichos peajes en los Decretos de adjudicación (en los correspondientes planes económico-financieros).

Pues bien, interesa destacar que, en torno a la fijación de las tarifas y peajes, se plantea el tema de las debidas compensaciones en favor del contratista, mediante la revisión de dichas tarifas.

En este sentido, la Ley 14/2000, de 28 de diciembre, de Acompañamiento a los Presupuestos Generales del Estado para 2001, establece el alcance, la forma y el procedimiento de las revisiones de las tarifas y peajes de las autopistas de peaje en régimen de concesión (puede verse el art. 77 y la disposición transitoria sexta).

Según el nuevo sistema la revisión de las tarifas y peajes se efectúa anualmente, teniendo en cuenta, por una parte, la variación anual producida en el índice de precios del consumo en los últimos doce meses respecto de la misma media de los doce meses anteriores (incremento del IPC medio) y, por otra parte, la correción de la desviación entre la intensidad media diaria real de tráfico que registró la autopista en los últimos doce meses y la intensidad media diaria que se había previsto por parte de la concesionaria. Este sistema significa en definitiva que los peajes subirán menos en aquellos tramos que registren tráficos superiores a los previstos y subirán más en los trayectos que no cumplan las expectativas de demanda. Además, las tarifas revisadas entrarán en vigor el 1 de enero de cada año, y no en el curso del mes de marzo como establecía el Real Decreto $210 / 1990$.

Para llegar a este régimen previsto en la citada Ley 14/2000 han tenido que superarse previamente ciertos problemas jurídicos que se reflejan en la propia evolución normativa del sector.

Primeramente, junto al RD 210/1990 mencionado, la Disposición Adicional vigésima de la Ley 13/1996, de 30 de diciembre, de Medidas Fiscales, Administrativas y del Orden Social, previó la adopción por parte del Estado de ciertas medidas con la finalidad de reducir el precio final del peaje para los usuarios de las autopistas en torno al 7,7 por 100 antes del 1 de septiembre de 1997, compensando a las sociedades concesionarias de autopistas del desequilibrio financiero que les pudiera suponer la reducción del peaje, mediante el otorgamiento de subvenciones a abonar por ejercicios vencidos. 
Pero por medio del Real Decreto 365/1997, de 14 de marzo, se aplazó esta medida de revisión prevista en la Ley 13/1996 hasta el día 1 de septiembre de 1997, de tal modo que se produjo una congelación de precios desde marzo hasta septiembre de 1997.

Esta «congelación» fue recurrida por las concesionarias de autopistas ante la jurisdicción contencioso-administrativa, quien les dio la razón, debiendo el Estado compensar a las empresas demandantes por la pérdida de ingresos sufri$\mathrm{da}{ }^{35}$.

Con posterioridad, se vuelve a incidir por el Estado en la rebaja del 7 por 100 de las tarifas en el Real Decreto-ley 6/1999, de 16 de abril de 1999, ya que en su artículo 8 (autopistas de peaje), convalidado por resolución de 29 de abril de $1999^{36}$, afirma que «a partir de la entrada en vigor de este Real Decreto-ley se iniciarán los trámites de revisión de los contratos de concesión de autopistas para rebajar las tarifas de peaje satisfechas por los usuarios en un 7 por 100 de su importe». Asimismo, «la Administración General del Estado, una vez cerrado cada ejercicio, liquidará a las sociedades concesionarias de su ámbito competencial por la pérdida de ingresos que les suponga la bajada de tarifas» ${ }^{37}$.

Finalmente, a través del Real Decreto 429/2000, de 31 de marzo, el Gobierno decretó una medida de congelación de tarifas similar a la de 1997, con el objeto de forzar a las concesionarias de autopistas a la adopción de un nuevo sistema o modelo de revisión de tarifas y peajes. Dicho sistema es el que se ha recogido en la Ley de Acompañamiento a los Presupuestos de 2001 que veíamos supra.

${ }^{35}$ Las SSTS de 6 de febrero de 1999 y de 12 de febrero de 2000 declaran, en primer lugar, «la ilegalidad del RD 365/1997, de 14 de marzo, sólo en cuanto fijó que las nuevas tarifas y peajes de las autopistas de titularidad de la Administración del Estado comenzarían a aplicarse el 1 de septiembre de 1997» y, en segundo lugar, «el derecho de las expresadas recurrentes a ser indemnizadas en la cantidad a fijar en ejecución de Sentencia, tomando, como base de la indemnización, la diferencia entre las tarifas y peajes prorrogados y las nuevas tarifas y peajes aprobados por la Administración para entrar en vigor a partir del dia 1 de septiembre y teniendo también en cuenta los vehículos que efectivamente hubieran transitado por los tramos de las autopistas concedidas entre el 20 de marzo de 1997 y el 1 de septiembre de 1997, según sus categorias desde el punto de vista tarifario. Y todo ello con los intereses legales correspondientes al periodo indicado, más los procedentes desde el día 1 de septiembre de 1997 y hasta el momento en que se produzca el pago efectivo y sin costas».

Por otra parte, ya la SAN de 26 de febrero de 1998 había anulado parcialmente la Resolución del Secretario de Estado de Infraestructuras y Transportes, de 20 de marzo de 1997, en el sentido de que en ella se deberia haber aprobado la revisión de tarifas, con efectos de 1 de septiembre de 1997.

36 Resolución de 29 de abril de 1999, de la Presidencia del Congreso de los Diputados, por la que se convalida el Real Decreto-ley 6/1999, de 16 de abril de 1999, de medidas urgentes de liberalización e incremento de la competencia (BOE de 6 de mayo de 1999, n. ${ }^{\circ} 108$ ).

${ }^{37}$ Puede verse la STS de 6 de febrero de 1999 Ar. 1968. Finalmente, «cuando el concedente sea una Comunidad Autónoma, la Administración General del Estado deberá celebrar convenios de colaboración con ésta a los efectos de fijar las actuaciones y financiación para llevar a cabo la liquidación a que se refiere el apartado anterior. En todo caso, el abono de las cantidades que pueda comprometer la Administración General del Estado en los convenios se efectuará una vez cerrado cada ejercicio". 
- Tercero, interesa hacer una referencia a la «ampliación» de las autopistas como medida que puede servir para hacer perdurar el contrato de concesión de obras públicas al mismo tiempo que debe realizarse un nuevo y ajustado equilibrio financiero entre las partes contratantes.

En el artículo 25 de la Ley de autopistas se regula primeramente el supuesto genérico de la ampliación de la autopista. Podrá ser aquélla acordada por la Administración estableciendo las particulares condiciones a que haya de sujetarse la realización de las obras y su repercusión en el régimen de tarifas para mantener el equilibrio económico-financiero de la concesión; o bien llegar a un convenio con el concesionario sobre los anteriores extremos manteniendo inalteradas las normas que rigieron para la adjudicación en todos aquellos extremos que no hayan sido objeto de modificación.

Cuando la ampliación consista en el aumento del número de carriles de las calzadas, para conseguir la mejor prestación del servicio público o para mejorar el sistema de comunicaciones del corredor afectado, podrá acordarse por convenio con el concesionario, en el que se establecerán aquellos aspectos del régimen concesional que sean objeto de modificación.

Excepcionalmente, la ampliación podrá consistir en la prolongación continua o funcional de la autopista, en el que se establecerán aquellos aspectos del régimen concesional que sean objeto de modificación. En este supuesto es preciso que concurran ciertos requisitos (subordinación de las obras a realizar respecto de las comprendidas inicialmente en la concesión y adjudicación mediante concurso abierto, aprobación por el Gobierno a propuesta del Ministerio de Fomento; el art. 25.2 en la redacción dada por Ley 66/1997).

Este régimen jurídico ha de servir para dar solución a los variopintos problemas que plantea el tráfico. En este sentido, la ampliación puede consistir en la construcción libre de peaje de un nuevo tramo como prolongación del existente repercutiéndose aquél en alguno de sus tramos ${ }^{38}$ o con revisión de tarifas ${ }^{39}$. Según la STS de 6 de febrero de 1999

\footnotetext{
${ }^{38}$ Real Decreto 483/1995, de 24 de marzo, de ampliación del tramo Mataró-Palafolls (Malgrat) de la autopista de peaje A-19 hasta su conexión con la carretera GE-600 de Blanes a Hostalric, con cruce sobre el río Tordera.

39 Real Decreto 158/1997, de 21 de enero, que modifica determinados términos de la concesión administrativa para la construcción, conservación y explotación de la autopista de peaje Villalba-Villacastín. Véanse también los Reales Decretos 1808/1994, de 5 de agosto, que modifica determinados términos de la concesión de la autopista de peaje Burgos-Cantábrico (Málzaga) y 1809/1994, de 5 de agosto, que modifica determinados términos de la concesión de la autopista de peaje del Atlántico.
} 
Ar. 1968 la revisión de tarifas no practicada en el momento procedente (determinado en el Pliego de condiciones) sino posteriormente, representa una alteración del equilibrio económico que origina una compensación en favor del concesionario.

Pero en la práctica una de las funciones más significativas de la «ampliación» es la de servir para mantener las actuales concesiones a cambio de que su titular se comprometa, al término de aquélla, a establecer mejoras en la autopista, nuevos carriles, manteniendo asimismo su conservación y explotación ${ }^{40}$.

En efecto, después de los párrafos legales que acaban de citarse, la Ley de autopistas prevé concretamente: «la compensación al concesionario con el objeto de mantener el equilibrio económico-financiero de la concesión en los supuestos de modificación o ampliación (vistos supra) podrá consistir total o parcialmente en la ampliación del plazo vigente de la concesión, en cuyo caso se podrán mantener los beneficios otorgados a la concesión o al concesionario por toda la extensión del plazo ampliado»». Asimismo se reconoce que «en las ampliaciones de plazo de la concesión deberá mantenerse el equilibrio económico-financiero de la concesión» (art. 25 bis.2).

Esta prórroga de la concesión, prevista en el artículo 25 bis, alcanza el límite máximo de 75 años en total (desde la fecha de entrada en vigor del Decreto de adjudicación tal como prevé el art. 30.1 de la misma Ley).

Este tipo de facultades han sido reforzadas jurisprudencialmente. En este sentido, la STS de 19 de febrero de 1999 Ar. 1526 admite que las cláusulas de la concesión adjudicada (en este caso por Decreto 165/1967, de 26 de enero, para la construcción, conservación y explotación de las autopistas Barcelona-La Junquera y Montgat-Mataró) en favor de ACESA puedan modificarse (en el presente supuesto con la finalidad de ampliar la autopista, incluyendo en Mataró una variante libre de peaje y la construcción de carriles libres adicionales).

Frente a la alegación de la demandante (Sindicat Unió de Pagesos de Catalunya) el Tribunal Supremo afirma que «el Real Decreto impugnado (al que se atribuye dicha modificación) se limita a hacer efectiva la potestad que a la Administración confiere el artículo 25 de la Ley 8/1972,

\footnotetext{
${ }^{40}$ Por ejemplo puede verse la noticia en el periódico El Pais (7 de noviembre de 1998) que informa acerca del pacto entre Fomento y ACESA, por el que la concesionaria se obliga a ampliar a tres carriles un tramo (entre Lérida y Zaragoza) y a realizar mejoras, prolongando a cambio la concesión.
} 
cuando señala que si en el futuro la autopista resultare insuficiente para la prestación del servicio y se considerare conveniente su ampliación por iniciativa de la Administración o a solicitud del concesionario, se procederá a la redacción de un convenio que recoja las particulares condiciones a que haya de sujetarse la realización de las obras y su repercusión en el régimen de tarifas, según las mismas normas que rigieron para la adjudicación en todos aquellos extremos que puedan ser mantenidos inalterables».

Un problema que se plantea es el de si en estos casos de ampliación de la autopista no se está eludiendo la garantía de concurso, prevista por otra parte en términos generales para la adjudicación de la concesión. Según la sentencia citada en último lugar "por esta misma razón, no puede considerarse aplicable la normativa estatal y comunitaria sobre contratación administrativa y de carreteras, a los efectos de que las nuevas obras sean sacadas a libre licitación. La Ley 8/1972 es de aplicación preferente a la construcción de autopistas en régimen de concesión, siendo supletoria la legislación de contratos del Estado (...)», «tratándose asimismo de una obra accesoria de la principal» ${ }^{4}$.

Otro problema que se ha planteado es el de si los Decretos de traspaso de competencias o servicios del Estado pueden llevar a impedir el convenio de ampliación de la autopista entre la concesionaria y el Estado. Frente a la alegación en este sentido del demandante en el supuesto de la STS de 17 de febrero de 1999 Ar. 1826, el TS deja claro que el traspaso de servicios del Estado a una Comunidad (por Real Decreto 1943/1980, de 31 de julio, sobre traspaso de servicios del Estado a la Generalidad de Cataluña en materia de carreteras) no significa modificación de las competencias que tenga atribuidas el Estado: "así las SSTC 147/1991 y 44/1992 puntualizan que los Reales Decretos de transferencias no definen competencias; la STC 149/1991 nos dice que los Reales Decretos de transferencias no vinculan a las Cortes Generales. Uno y otro aspecto tiene su razón de ser en que los Reales Decretos de transferencias tienen una finalidad instrumental (STC 329/1994)». De este modo esta sentencia aprueba ciertas condiciones establecidas por el Estado y ciertas reservas en su favor respecto de la facultad de construir, conservar y explotar nuevas carreteras de interés nacional, así como la ampliación de la autopista objeto de litigio, conforme al artículo 25 de la Ley de Autopistas.

\footnotetext{
41 Igualmente puede verse la STS de 17 de febrero de 1999, Ar. 1826, FJ 5. ${ }^{\circ}$, donde el TS admite la modificación de determinadas cláusulas de la concesión en favor de Autopistas Concesionaria Española, S. A., declarando válido el Real Decreto 1547/1990.
} 
REAL 285 (ENERO-ABRIL, 2001)

Finalmente, es preciso dejar claro que la Administración puede decretar las modificaciones de las obras decretadas inicialmente (conforme al ius variandi), siempre que compense como es debido al concesionario como consecuencia de la alteración del equilibrio económico de la concesión que representa dicha modificación (STS de 21 de abril de 1983, Ar. 1956, ante la modificación del proyecto inicial de obras, decretando la ampliación de las obras respecto de un ramal nuevo; STS de 15 de junio de 1983, Ar. 3528). 